\title{
EFEKTIVITAS PENGGUNAAN PENDEKATAN PEMBELAJARAN REALISTIC MATHEMATIC EDUCATION (RME) DENGAN BERBANTUAN MEDIA PEMBELAJARAN APLIKASI KAHOOT
}

\author{
Rica Wijayanti ${ }^{1}$, Didik Hermanto ${ }^{2}$ Zainuddin $^{3}$ \\ 1,2,3 Program Studi Pendidikan Matematika, STKIP PGRI Bangkalan \\ Email: ricawijayanti@stkippgri-bkl.ac.id
}

\begin{abstract}
Abstrak:
Tujuan penelitian ini adalah untuk menguji apakah pendekatanRealistic Mathematic Education (RME) dengan berbantuan media pembelajaran aplikasi kahoot efektif digunakan dalam proses pembelajaran atau tidak. Keefektifan pada penelitian ini dilihat dengan cara membandingkan hasil belajar siswa pada kelas eksperimen dan kelas kontrol.Jenis penelitian yang digunakan dalam penelitian ini adalah penelitian quasi eksperiment (eksperimen semu).Pada penelitian ini rancangan penelitian yang akan digunakan adalah membagi subyek penelitian menjadi dua kelas yaitu kelas eksperimen dan kelas kontrol. Instrumen yang digunakan dalam penelitian ini adalah lembar pretest dan posttest. Sebelum menguji keefektivan dari pendekatan dan media yang digunakan, peneliti terlebih dahulu menguji apakah kedua kelas yang digunakan berdistribusi normal dan homogen atau tidak.Hasil analisis data yang diperoleh pada penelitian ini menunjukkan bahwa kedua kelas yang dipilih sebagai subyek penelitian berdistribusi normal dan homogen. Oleh karena itu, peneliti menggunakan uji t untuk menguji keefektifan. Hasil dari $t_{\text {hitung }}$ sebesar 8,46 dan $t_{\text {tabel }}$ sebesar 2,07. Karena $t_{\text {hitung }}>$ $t_{\text {tabel }}$, maka dapat disimpulkan bahwa $H_{1}$ diterima dan $H_{0}$ ditolak. Artinya, pendekatan Realistic Mathematic Education (RME) dengan berbantuan media pembelajaran aplikasi kahoot efektif digunakan dalam proses pembelajaran matematika
\end{abstract}

Kata Kunci:Efektivitas, Pendekatan RME dan Media Pembelajaran Kahoot

\section{Pendahuluan}

Indonesia telah memasuki era baru yaitu era industri 4.0 sehingga berbagai bidang mengalami perubahan yang signifikan.Salah satu bidang yang mengalami perubahan mengikuti perkembangan era industri 4.0 adalah bidang pendidikan.Menurut (Abdullah, 1999)Pendidikan di Indonesia mulai meninggalkan proses pembelajaran yang berpusat pada guru atau yang lebih dikenal dengan istilah teacher center dan mulai beralih pada proses pembelajaran yang berpusat pada siswa atau student center. Selain proses pembelajaran yang berubah, media pembelajaran yang digunakan juga mengalami perubahan yaitu dengan memanfaatkan teknologi.

Perubahan yang terjadi ini tidak lain dengan tujuan agar proses pembelajaran menjadi lebih baik lagi karena dengan menggunakan pembelajaran student center pengetahuan dapat dikonstruk sendiri oleh siswa melalui pengalaman-pengalaman belajar mereka yang sebelumnya. Pengetahuan yang dikonstruk sendiri oleh siswa dapat tersimpan baik pada memori jangka panjang mereka, sehingga pengetahuan yang didapat di sekolah lebih lama melekat dalam pikiran siswa.

Selain itu, proses pembelajaran yang tidak lagi berpusat pada guru dapat membuat siswa menjadi lebih aktif dan lebih mandiri. Hal ini dibuktikan oleh hasil penelitian yang dilakukan oleh (Nelvi Noviza, 2017). Dalam penelitian tersebut, siswa lebih aktif ketika proses pembelajaran beralih tidak berpusat pada guru dan siswa juga mampu menyelesaikan masalah yang diberikan oleh guru secara mandiri bersama teman-teman kelompoknya. Siswa akan terbiasa dihadapkan pada permasalahanpermasalahan dan mencari sendiri solusi dari permasalahan-permasalahan tersebut. Oleh karena itu, seorang guru harus kreatif dalam mengolah proses pembelajaran. Salah satu ciri guru yang kreatif dalam mengolah pembelajaran adalah menggunakan sebuah pendekatan pembelajaran yang disesuaikan dengan materi pelajaran. 
Pendekatan pembelajaran Realistic Mathematic Education (RME) adalah suatu pendekatan yang cocok digunakan oleh guru untuk mengajarkan mata pelajaran matematika.Realistic Mathematic Education (RME) menurut (Yerizon, 2013) merupakan suatu pendekatan dengan paradigma bahwa matematika adalah suatu kegiatan manusia, dan belajar matematika berarti bekerja dengan matematika (doing mathematic). Seiring dengan pendapat Yerizon, (Desvita, 2014) menganggap bahwa Realistic Mathematic Education (RME) merupakan pendekatan pembelajaran matematika di sekolah yang bertitik tolak dari hal-hal real bagi kehidupan siswa.

Proses pembelajaran dengan menggunakan pendekatan Realistic Mathematic Education (RME) pertama kali dikenalkan oleh Frudenthal. Menurut pandangan Frudental matematika yang diajarkan pada siswa harus dihubungkan dengan realitas, tetap dekat dengan dunia siswa, dan relevan dengan kehidupan sosial masyarakat serta nilai-nilai kemanusiaan. Hal ini secara tidak langsung menunjukkan pada siswa bahwa ilmu matematika yang mereka pelajari dapat diaplikasikan untuk memecahkan masalah kehidupan nyata siswa.

Menurut (Panhuizen, 1996) menganggap bahwa yang dimaksud nyata bukan sebatas apa yang nyata pada pandangan siswa tetapi juga semua hal yang dapat dibayangkan dan dijangkau oleh imajinasi siswa. Seiring dengan hal tersebut, (Marsigit, 2014) berpendapat bahwa pendekatan realistik dpaat mengubah otoritas guru yang semula sebagai satu-satunya sumber pengetahuan menjadi seorang fasilitator. Jika peran guru sudah berubah menjadi seorang fasilitator, maka kegiatan pembelajaran dapat berjalan tidak hanya dimulai dari masalah nyata melainkan juga memberi kebebasan kepada siswa untuk dapat mendeskripsikan, menginterpretasikan dan menyelesaikan masalah-masalah mereka dengan caranya sendiri menggunakan bekal pengetahuan awal yang dimiliki oleh siswa.

Berdasarkan hasil penelitian yang dilakukan oleh (Jasmita, 2013) menyatakan bahwa pendekatan Realistic Mathematic Education (RME) memiliki beberapa keunggulan yaitu:

a. Suasana dalam proses pembelajaran menyenangkan karena menggunakan realitas yang ada di sekitar siswa.

b. Siswa tidak mudah lupa tentang materi yang diajarkan keran mereka membangn sendiri pengetahuannya

c. Siswa akan terbiasa berfikir dan berani mengemukaakn pendapat

d. Siswa dapat secara langsung mengimplementasikan ilmu matematika dalam pemecahan masalah sehari-hari.

Selain menggunakan pendekatan, proses pembelajaran akan lebih berpusat pada siswa jika guru menggunakan media pembelajaran yang sesuai dengan perkembangan zaman dan perkembangan siswa saat ini. Menurut (Munadi, 2008) media pembelajaran adalah segala sesuatu yang digunakan untuk menyampaikan dan menyalurkan pesan atau informasi dari pengirim ke penerima pesan secara terencana sehingga terjadi proses belajar yang efisien dan efektif

Media pembelajaran yang sesuai dengan perkembangan zaman adalah media pembelajaran yang memanfaatkan teknologi, sedangkan media pembelajaran yang sesuai dengan perkembangan siswa adalah game edukasi. Menurut (Hermawan, 2017)game edukasi diartikan sebagai proses pembelajaran yang dikemas dalam sebuah permainan. Penggunaan game edukasi dapat memberikan suasana pembelajaran lebih menyenangkan.Game edukasi yang digemari dan cocok untuk zaman sekarang adalah game dalam bentuk aplikasi android. Aplikasi android yang dapat digunakan sebagai game edukasi adalah aplikasi kahoot.

Menurut (Iwamoto, 2017) Aplikasi Kahoot adalah aplikasi online dimana kuis yang berupa soal-soal tes akan dikembangkan dalam format permainan, dan pemberian poin akan diberikan kepada siswa yang menjawab benar dan cepat semakin cepat dan jawaban benar maka akan semakin tinggi poin yang diperoleh. Siswa yang ikut dalam permainan namanya akan tercantum kedalam daftar pemain.Seiring dengan pendapat tersebut, 
menurut (Muhammad, 2018) Aplikasi Kahoot merupakan platform pembelajaran yang berbasis game dan aplikasi ini merupakan media yang bisa digunakan untuk guru dalam proses pembelajaran agar menjadi menyenangkan. Kelebihan dari penggunaan aplikasi kahoot menurut (Ismail, 2016) yaitu (1) dapat membuat siswa berada dalam situasi persaingan yang sehat; (2) hasil dari kuis pada aplikasi kahoot akan langsung terpapar dalam layar yang ditampilkan menggunakan LCD; (3) dapat memotivasi siswa agar berusaha menjawab dengan benar dan cepat; (4) dapat dimainkan menggunakan handphone android..

\section{MetodePenelitian}

Tujuan penelitian ini adalah untuk menguji apakah pendekatanRealistic Mathematic Education (RME) dengan berbantuan media pembelajaran aplikasi kahoot efektif digunakan dalam proses pembelajaran atau tidak. Jenis penelitian yang digunakan dalam penelitian ini adalah penelitian quasi eksperiment (eksperimen semu). Pada penelitian ini rancangan penelitian yang akan digunakan adalah membagi subyek penelitian menjadi dua kelas yaitu kelas eksperimen dan kelas kontrol. Desain penelitian akan ditunjukkan seperti tabel berikut.

Tabel 1.Desain Penelitian Eksperimen Semu

\begin{tabular}{lccc}
\hline Kelas & Pretes & Perlakuan & Posttest \\
\hline $\begin{array}{l}\text { Eksperi } \\
\text { men }\end{array}$ & Y1 & $\mathrm{X}$ & Y2 \\
Kontrol & Y1 & & Y2 \\
\hline
\end{tabular}

Keterangan :

(Sudjana \& Ibrahim, 2001)

$\mathrm{Y} 1=$ Kemampuan Awal Peserta Didik

$\mathrm{X}=$ Pemberian Perlakuan (Penggunaan Model RME dengan berbantuan media pembelajaran aplikasi kahoot)

Y2 = Kemampuan Akhir Peserta Didik Variabel yang digunakan dalam penelitian ini ada dua variabel yaitu variabel bebas dan variabel terikat.Variabel bebas pada penelitian ini adalah penggunaan model pembelajaran Realistic Mathematic Education (RME) dengan berbantuan media pembelajaran aplikasi kahoot, sedangkan variabel terikatnya adalah hasil belajar peserta didik. Penelitian ini akan dilakukan di SDN Jukong 2 Kecamatan Labang Kabupaten Bangkalan dengan menggunakan dua kelas yaitu kelas kontrol dan kelas eksperimen.

Instrumen penelitian adalah alat atau fasilitas yang digunakan oleh peneliti dalam mengumpulkan data agar pelaksanaan penelitian lebih mudah dan memperoleh hasil yang sesuai dengan yang diharapkan.Instrumen yang digunakan dalam penelitian ini adalah lembar tes hasil belajar yang terdiri dari lembar pretest dan lembar posttest. Lembar pretest diberikan sebelum sampel penelitian diberikan perlakuan sedangkan lembar posttest diberikan setelah sampel penelitian diberikan perlakuan

Teknik pengumpulan data pada penelitian ini menggunakan metode tes.Metode tes dilakukan untuk memperoleh hasil belajar siswa. Tes akan diberikan sebanyak 2 kali yaitu di awal sebelum sampel diberikan sebuah perlakuan dan di akhir setelah sampel diberikan sebuah perlakuan.Setelah peneliti memperoleh data penelitian, maka peneliti akan mengolah data tersebut dengan cara melakukan analisis data. Data penelitian ini akan dianalisis dengan menggunakan teknik statistik deskriptif dan statistik inferensial. Teknik statistik deskriptif akan digunakan untuk mendeskripsikan hasil tes dari siswa baik pada kelas eksperimen maupun kelas kontrol. Sedangkan teknik statistik inferensial digunakan untuk menguji hipotesis yang meliputi uji normalitas, uji homogenitas varians dengan menggunakan bantuan SPSS.

\section{Hasil dan Pembahasan Hasil}

Sebelum peneliti memberikan perlakuan pada kelas eksperimen, peneliti memberikan pretest.Pemberian pretest juga dilakukan oleh peneliti pada kelas kontrol. Hasil pretest ini akan dibandingkan dengan hasil posttest untuk mengetahui apakah dua kelas yang dijadikan sampel homogen atau 
tidak. Berikut ini adalah data hasil pretest dan posttest.

Tabel 2. Perbandingan Hasil Pretest dan Posttest Kelas Kontrol

\begin{tabular}{cccc}
\hline \multirow{2}{*}{ No } & \multicolumn{3}{c}{ Kelas kontrol } \\
\cline { 2 - 4 } & Pretest & Posttest & Gain Skor \\
\hline 1 & 67,5 & 72,5 & 5 \\
2 & 65 & 75 & 10 \\
3 & 70 & 80 & 10 \\
4 & 70 & 80 & 10 \\
5 & 60 & 80 & 20 \\
6 & 73 & 80 & 7 \\
7 & 65,5 & 77,5 & 12 \\
8 & 70 & 75 & 5 \\
9 & 75 & 85 & 10 \\
10 & 77 & 85 & 8 \\
11 & 71 & 80 & 9 \\
12 & 65 & 70 & 5 \\
\hline Rata- & 69,1 & 78,3 & 9,3 \\
Rata & & & \\
\hline
\end{tabular}

Tabel 3. Perbandingan Hasil Pretest dan Posttest Kelas Eksperimen

\begin{tabular}{cccc}
\hline \multirow{2}{*}{ No } & \multicolumn{3}{c}{ Kelas kontrol } \\
\cline { 2 - 4 } & Pretest & Posttest & Gain Skor \\
\hline 1 & 75 & 95 & 20 \\
2 & 62,5 & 82,5 & 20 \\
3 & 75 & 90 & 15 \\
4 & 75 & 90 & 15 \\
5 & 65 & 85 & 20 \\
6 & 72,5 & 92,5 & 15 \\
7 & 70 & 82 & 12 \\
8 & 72 & 90 & 18 \\
9 & 67,5 & 82,5 & 15 \\
10 & 70 & 80 & 10 \\
11 & 65 & 80 & 15 \\
12 & 62,5 & 82,5 & 20 \\
\hline Rata- & 69,3 & 86,0 & 16,3 \\
Rata & & & \\
\hline
\end{tabular}

Berdasarkan data di atas, kemudian dilakukan perhitungan statistik deskriptif sehingga diperoleh varians sebsar 16,93 untuk kelas eksperimen dan 11,29 untuk kelas kontrol. Selanjutnya hasil tersebut digunakan untuk menghitung nilai dari $F_{\text {hitung }}$ dengan menggunakan rumus

$$
F=\frac{\text { variansiterbesar }}{\text { variansiterkecil }}
$$

Hasil dari perhitungan $F_{\text {hitung }}$ sebesar 1,49 sedangkan $F_{\text {tabel }}$ sebesar 2,82.
Karena $F_{\text {hitung }}<F_{\text {tabel }}$, maka dapat disimpulkan bahwa distribusi data yang akan dianalisis adalah homogen dan normal. Langkah selanjutnya adalah melakukan uji hipotesis dengan menggunakan uji t. Berdasarkan hasil analisis data dengan menggunakan uji $\mathrm{t}$ diperoleh hasil $t_{\text {hitung }}$ sebesar 8,46. Hasil $t_{\text {hitung dibandingkan dengan hasil } t_{\text {tabel }}}$ yaitu 2,07. Karena $t_{\text {hitung }}>t_{\text {tabel }}$, maka dapat disimpulkan bahwa $H_{1}$ diterima dan $H_{0}$ ditolak. Artinya, pendekatan Realistic Mathematic Education (RME) dengan berbantuan media pembelajaran aplikasi kahoot efektif digunakan.

\section{Pembahasan}

Pada penelitian ini kelas eksperimen diberikan perlakuan menggunakan pendekatan Realistic Mathematic Education (RME) dengan berbantuan media pembelajaran aplikasi kahoot. Sebelum pemberian perlakuan baik kelas kontrol maupun kelas eksperimen sama-sama diberikan soal pretest. Hal ini bertujuan agar sebelum dilakukan uji hipotesis, dapat dipastikan terlebih dahulu bahwa dua kelas yang dijadikan sampel penelitian berdistribusi normal dan homogen.

Berdasarkan hasil analisis data di atas, maka dapat dibuktikan bahwa sampel yang dipilih berdistribusi normal dan homogen. Setelah terbukti kedua sampel yang digunakan berdistribusi normal dan homogen, langkah selanjutnya adalah peneliti memberikan perlakuan dengan cara menerapkan proses pembelajaran matematika menggunakan pendekatan Realistic Mathematic Education (RME) dengan berbantuan media pembelajaran aplikasi kahoot yang sudah dibuat sebelumnya.

Setelah proses pemberian perlakuan selesai dilakukan, langkah selanjutnya adalah penelitti memberikan soal post testt. Soal posttest ini digunakan untuk uji hipotesis. Soal post test bukan hanya digunakan pada kelas eksperimen mealinkan juga pada kelas kontrol. Berdasarkan hasil data dari posttest menunjukkan bahwa semua siswa mengalami peningkatan lebih baik 
dibandingkan saat mereka mengerjakan soal pretest. Namun, peningkatan yang paling signifikan nampak pada kelas yang diberikan perlakuang dengan menerapkan pendekatan Realistic Mathematic Education (RME) dengan berbantuan media pembelajaran aplikasi kahoot. Hal ini menunjukkan bahwa pendekatan dan media pembelajaran yang digunakan sudah efektif jika ditinjau dari hasil belajar siswa.

Data dari hasil pretest dan posttest kemudian dianalisis dengan menggunakan uji t. Hasil dari analisis uji te menunujkkan bahwa $t_{\text {hitung }}>t_{\text {tabel }}$ sehingga dapat disimpulkan bahwa pendekatan Realistic Mathematic Education (RME) dengan berbantuan media pembelajaran aplikasi kahoot efektif digunakan.

Hasil penelitian ini yang membuktikan bahwa pendekatan Realistic Mathematic Education (RME) efektif digunakan dalam proses pembelajaran matematika sejalan dengan hasil penelitian yang dilakukan oleh (Achmad, 2011). Namun, walaupun hasil penelitian samasama menunjukkan keefektifan penggunaan pendekatan Realistic Mathematic Education (RME) tetapi penelitian ini memiliki perbedaan dengan penelitian yang dilakukan achmad. Perbedaan tersebut terletak pada indikator keefektifannya. Penelitian yang dilakukan Achmad melihat keefektifan dilihat dari pemahaman konsep siswa sedangkan pada penelitian ini keefektifan dilihat dari hasil belajar pada kelas eksperimen dan kelas kontrol.

Sedangkan untuk hasil penelitian lain yang menunjukkan keefektifan penggunaan aplikasi kahoot telah dilakukan sebelumnya oleh (Sari, 2017). Persamaan penelitian ini dengan penelitian sari adalah media yang digunakan sama-sama menggunakan aplikasi kahoot dan hasilnya juga samasama efektif digunakan selama proses pembelajaran. Sedangkan untuk perbedaannya adalah pada penelitian Sari subyek penelitiannya adalah anak paud dan pada penelitian ini subyeknya anak sekolah dasar. Selain itu, aplikasi kahoot pada penelitian ini berfungsi sebagai media pembelajaran yang dapat membuat siswa menjadi lebih aktif, sedangkan aplikasi pada penelitian sari digunakan sebagai media pembelajaran yang dapat menumbuhkembangkan jiwa kompettif dan kolaboratif anak.

Penelitian tentang kolaborasi antara pendekatan Realistic Mathematic Education (RME) dengan berbantuan media pembelajaran aplikasi kahoot sendiri merupakan penelitian baru yang belum pernah dilakukan oleh peneliti lain sebelumnya. Namun, untuk penelitian tentang keefektivan penggunaan pendekatan Realistic Mathematic Education (RME) dan media berbasis teknologi yang lain sudah banyak dilakukan. Salah satunya yaitu penelitian yang dilakukan oleh (Rahmawati, 2016). Hasil penelitian Noviana menunjukkan hal yang sama bahwa pengunaan pendekatan Realistic Mathematic Education yang dikolaborasi dengan media berbasis teknologi efektif digunakan saat proses pembelajaran berlangsung. Namun, perbedaannya adalah jika penelitian ini menggunakan media berbasis teknologi berbentuk aplikasi kahhot, jika penelitian Noviana media yang digunakan adalah multimedia interaktif.

\section{Simpulan dan Saran \\ Simpulan}

Berdasarkan hasil analisis data penelitian yang dilakukan, maka dapat ditarik sebuah kesimpulan bahwa pendekatan Realistic Mathematic Education (RME) dengan berbantuan media pembelajaran aplikasi kahoot efektif digunakan dalam proses pembelajaran matematika. Hasil belajar yang dimaksud dalam penelitian ini yaitu adanya perubahan nilai pretest yang lebih meningkat setelah proses pembelajaran dilakukan menggunakan pendekatan Realistic Mathematic Education (RME) dengan berbantuan media pembelajaran aplikasi kahoot.

\section{Saran}

Adanya hasil penelitian yang menunjukkan bahwa Realistic Mathematic Education (RME) dengan berbantuan media pembelajaran aplikasi kahoot efektif digunakan, maka peneliti menyarankan kepada guru-guru di sekolah khususnya 
guru-guru yang mengajar di Sekolah Dasar dapat menggunakan Realistic Mathematic Education (RME) sebagai alternatif pendekatan pembelajaran dan aplikasi kahoot sebagai alternatif media pembelajaran matematika. Selain itu, disarankan kepada guru agar sebelum menggunakan pendekatan Realistic Mathematic Education (RME) dengan berbantuan media pembelajaran aplikasi kahoot menelaah terlebih dahulu bahan ajar yang akan disampaikan, karena tidak semua bahan ajar cocok menggunakan pendekatan dan media ini. Pendekatan Realistic Mathematic Education (RME) dengan berbantuan media pembelajaran aplikasi kahoot cocok digunakan saat menyampaikan bahan ajar yang dapat diaplikasikan dalam kehidupan nyata siswa.

\section{DaftarPustaka}

Abdullah.1999. Pengembangan Kurikulum Teori dan Praktik. Jakarta: Gaya Media Pratama.

Achmad. 2011.Efektivitas Pembelajaran Matematika melalui Model Pembelajaran Realistic Mathematic Education terhadap Peningkatan Pemahaman Konsep Matematika di $S D$. Jurnal Pendidikan, 33-40.

Desvita, E. 2014.Efektivitas Pendekatan Realistic Mathematic Education (RME) dengan Menggunakan LKS dalam Pembelajaran Matematika Kelas VIII MTs Muhammadiyah Padang. Jurnal FKIP UMSB.

Hermawan, D. P. 2017. Efektivitas Penggunaan Game Edukasi Berjenis Puzzle, RPG dan Puzzle RPG Sebagai Sarana Belajar Matematika. Jurnal Ilmiah Teknologi Informasi , 195-205.

Ismail, A. N. 2016. Keberkesanan Penggunaan Quizlet dan Kahoot IT dalam memperkasakan Pengajaran Guru dan Memperkaya Pembelajaran Murid.Edumath .
Iwamoto, D. 2017. Analyzing The Of The Testing Effect Using Kahoot On Student Performance. Turkish Oline Journal of Distance Education .

Jasmita, N. H. 2013. Ketuntasan Hasil Belajar Siswa Melalui Pendekatan ealistic Mathematic Education (RME) Pada Materi Perkalian.Didaktika , 212-222.

Marsigit, A. Z. 2014. Perbandingan Keefektifan Pembelajaran Matematika dengan Pendekatan Matematika Realistik dan Konvensional Ditinjau dari Kemampuan Penalaran dan Komunikasi Matematik Siswa. Jurnal Riset Pendidikan Matematika , 152163.

Muhammad, Y. 2018. Implementation Of Kahoot Aplication To Improving $\mathrm{Or}$ Interest Of Civic Education Learning Experimental Research In Class XI Of SMAN 1 Garut .Jurnal Civic \& Social Studies .

Munadi, Y. 2008. Media Pembelajaran Sebuah Pendekatan Baru. Jakarta: GP Press.

Nelvi N, F. 2017. Peningkatan Aktivitas Belajar Matematika Siswa Kelas VII MTSN 1 Kota Bengkulu dengan Model Pembelajaran Talking Stick. Jurnal Penelitian Pembelajaran Sekolah , 41-46.

Rahmawati, N. D.2016. Efektivitas Penggunaan Multimedia Interaktif dengan Pendekatan Matematika Realistik pada Mata Kuliah Matematika SMA. JKPM- UNIMUS , 27--36.

Panhuizen, V. d. 1996.Mathematics Education In The Netherlands : A Guide Tour. Utrecht: Frudenthal Institute, Utrecht University. 
Sari, F. R. 2017.Penggunaan Platform Kahoot Menumbuhkembangkan dalam Jiwa Kompettif dan Kolaboratif Anak. Jurnal Anak Usia Dini dan Pendidikan Anak Usia Dini, 164-172.

Sudjana. 2005. Metoda Statistika. Bandung: PT. Tarsito Bandung.ISBN 9799185-37-8.

Yerizon, A. F. 2013. Pengaruh Pendekatan Realistic Mathematic Education (RME) dan Kemandirian Belajar terhadap Kemampuan Matematis Siswa. Padang:Semirata FMIPA Universitas Lampung. 